\title{
A TÁRSADALMI KIREKESZTÉS ÉS A LAKÓTELEPEK
}

\author{
(Social Exclusion and the Housing Estates)
}

\author{
EGEDY TAMÁS
}

Kulcsszavak:

Lakáspiac, szegregáció, lakótelep

A rendszerváltozás után az egyes lakótelepi generációk lakásai eltérô eséllyel indultak a lakáspiacon és léptek be a privatizációs folyamatba. A lakásárak szabályozó hatására a lakótelepek különbözö generációinak népességében megindult egyfajta „letisztulási” folyamat, amelynek követeztében ezen generációknál - több kísérôjelenséggel együtt - egyre inkább felismerhetỏ az egységes lakásosztályokká történỏ átalakulás folyamata.

\section{Bevezetés}

A lakótelepek a lakáspiac sajátos részeit képezik, méretük, elhelyezkedésük, homogenitásuk és végül, de nem utolsó sorban társadalmi szerkezetük miatt. Nem tekinthetök kizárólag a korábbi szocialista államrendszer termékeinek, hiszen megtalálhatók Nyugat-Európában is, habár az ottaniak jelentősége és szerepe lényegesen eltér szocialista rokonaikétól. Bár nyugaton is fontos részei a lakáspiacnak, csupán kis részét képezik a lakásállománynak. Ennek ellenére az 1980-as évek elejétöl majdnem mindegyik nyugat-európai kormány kísérletet tett egy átfogó lakótelepi revitalizálási program megvalósítására, hogy elsősorban a problémás lakótelepekêt modernizálja és rehabilitálja (Dunleavy 1981; Herlyn 1989; van Kempen-Musterd 1991).

A lakótelepekkel kapcsolatos problémák sokkal szembetủnőbben jelentkeznek Kelet-Közép-Európában, hiszen az itt található lakások száma és lakáspiacon játszott szerepük messze meghaladja a nyugat-európai szintet (Müller 1997; Rietdorf-Liebmann-Knorr-Siedow 1994). Söt ezekben az országokban még nem fejeződtek be a felújitási munkálatok sem. Az 1989-es politikai változások következtében a poszt-szocialista államokban mély társadalmi-gazdasági átalakulás indult meg. Egyrészt a bérek és a munkaerö-piaci lehetőségek differenciáló hatására a társadalmi különbségek rohamos növekedésének lehettünk tanúi, másrészt az önkormányzati lakások privatizációjával az állam szerepe jelentéktelenné vált a városok lakáspiacán. A megmaradt állami lakásállomány - különösen a kevésbé népszerübb és piacképes formák, mint a városszéli többemeletes lakótelepek lakásai - egyre inkább a szegények menedéke lett a poszt-szocialista városokban. Így a lakáspolitika, vagy annak hiánya és a lakáspiac müködése nagyban hozzájárult egyes társadalmi rétegek szegregációjához. Ebben a tanulmányban megvilágítjuk a társadalmi kirekesztés néhány jellemzőjét a budapesti lakótelepeken. 


\section{1. ÁBRA}

Budapest 1945 után épült lakótelepei

(Housing Estates in Budapest Built after 1945)

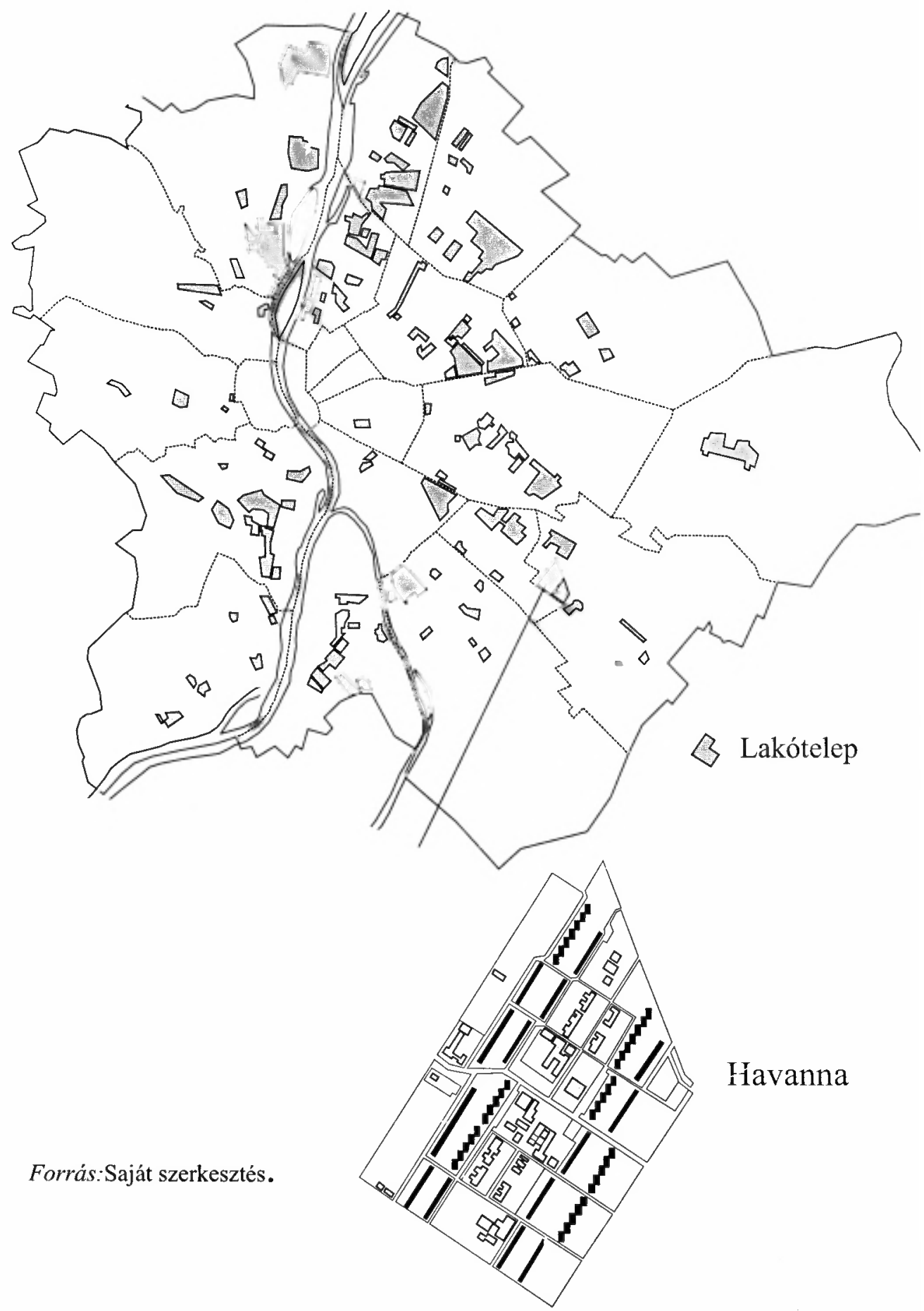


Kiindulási alapul a XVIII. kerületi önkormányzat 1998-ban 117, gyermekes cigánycsalád körében végzett felmérésének eredményeit vettük, s ezeket kiegészíttük saját interjúink eredményeivel, melyeket a főváros egyik tipikusan problémás lakótelepén, a Havanna lakótelepen élő magyar és roma családokkal készítettünk. Kutatásunk során kiemelt hangsúlyt fektettünk a szegregáció mechanizmusának feltárására, illetve a lakások, munkalehetöségek és szolgáltatások színvonalának különbségeire. Különös figyelmet szenteltünk a társadalmi kirekesztés különféle tényezőire, úgy mint etnikai kérdések, szegénység, munkaerő-piaci helyzet, a lakók helyi aktivitása.

\section{A II. világháború után épült lakótelepek}

Az 1996. évi mikrocenzus adatai alapján Magyarországon 785000 lakás található lakótelepeken, ami a lakásállomány 20\%-a. Budapesten a lakások 33\%-a volt lakótelepi, bár ez az arány folyamatosan csökkent az elmúlt tíz év alatt. A lakótelep ötlete és az első lakótelepek megjelenése is a századforduló környékére tehetö, bár jelentösebb elterjedésükre csak a II. világháború után került sor (1.ábra). Már az elején hangsúlyoznunk kell, hogy a magyar lakótelepek helyzete messze sem annyira rossz, mint más kelet-európai országokban. Köszönhetö ez többek között annak, hogy Magyarországon a szocialista időszakban nem érvényesült olyan erősen a szélsőséges Sztálini-modell a város és lakásépítési politikában (pl. bulldózeres városrendezés). 1956-tól, de különösen az 1968-as gazdasági reformok után Magyarország egyfajta „harmadik utat” kezdett járni a keleti blokkon belül, amit gyakran „gulyás kommunizmusként” emlegetnek. A lakásépítésben támogatták a magán- és szövetkezeti szektor részvételét, és maga az állam is elősegítette egyfajta kvázi-piaci mechanizmus kialakulását és müködését. Az állami és ezen belül a lakótelepi lakások azonban országos szinten sohasem uralták igazán a piacot.

A lakótelepeken röviddel felépülésük után megjelentek különböző kísérőjelenségek, amelyek mára társadalmi problémákká nőtték ki magukat. Figyelembe véve fizikai megjelenésüket, méretuiket, építési anyagukat és technológiájukat lakótelepek különböző generációiról beszélhetünk, amelyek természeti és társadalmi környezete is jelentős eltéréseket mutat. Ennek megfelelöen a fent említett problémák is eltérő módon jelentkeznek e lakótelepi generációk esetében (Hegedüs 1987; Kovács-Douglas 1996; Szelényi 1990).

\section{Az 1950-es évek lakótelepei}

A lakótelepek kijelölésékor a tervezők törekedtek arra, hogy az építkezés a legkisebb járulékos költségekkel járjon, ezért ezek a lakótelepek leggyakrabban a belső városrészeket övezö, közművel már ellátott, vagy könnyen ellátható 
területeken épültek fel (Preisich 1998). Az 1950-es évek lakótelepei „emberi léptékü" méretükkel tünnek $\mathrm{ki}$, az épületek magassága nem haladta meg a 3-4 szintet, a beépített lakások száma általában 300-800 között alakult. A legtöbb lakótelep jól illeszkedett történetileg kialakult környezetéhez.

Az 1950-es években megépült lakótelepi lakások javulást hoztak az emberek életébe. Igaz, az egyszobás lakások aránya rendkívül magas volt (52\%), lakásnagyság tekintetében tehát semmiképpen sem beszélhetünk előrelépésröl. A lakások komfortfokozata azonban összességében javult, hiszen az átadott lakások legtöbbje már fürdőszobával rendelkezett.

$\mathrm{Az}$ évtized második felében a szocialista realizmus megszünt, $s$ helyébe a modern építészeti ideológia lépett. Megjelent a típustervezés, mely nagyban hozzájárult ezen lakótelepek építészeti színvonalának csökkenéséhez.

\section{Az 1960-as évek lakótelepei}

Az 1960-as évtized mind az épített lakások mennyiségében, mind az építkezések jellegében alapvető változásokat hozott. Az évtized lakótelepei elsősorban a belső városrészek körüli átmeneti zónában épültek fel, megindult tehát a lakótelepi épitkezések kifelé tolódása. Kedvezőbben alakult a lakások összetétele: megnőtt a kétszobás, a fürdőszobás és a központi fütéssel ellátott lakások aránya.

$\mathrm{Az}$ évtized második felében és a hetvenes évek elején megvásárolták az első házgyárakat, ami a paneles technológia elterjedését hozta magával. Az 1960-as évtizedben általánossá vált a lakásépítésben különbözö normák, valamint típustervek felállítása és alkalmazása. Ebben az évtizedben terjedt el a modern építészet elveinek alkalmazása is.

E lakótelepek presztízse lényegesen magasabb a következő évtizedben felépültekénél. A hatvanas években ugyanis a budapesti társadalom magasan kvalifikált, vezetó beosztású és értelmiségi rétegei, többgyerekes fiatal családok a belsö városrészekböl föként ezekre az új lakótelepekre költöztek be (CsanádiLadányi 1992; Szelényi-Konrád 1969).

\section{Az 1970-es évek lakótelepei}

Az 1970-es évtized lakásépítés szempontjából a lakótelepek történetének legeredményesebb időszaka volt. Az 1970-es évek lakótelepeinek beépítési módját és építészeti karakterét egyre inkább a szovjet mintájú nagypaneles technológia határozta meg, ami sikeresen hozzájárult az egyik eröltetett célkitüzés megvalósitásához: a lakások előállítási árának minimalizálásához. Az 1970-es években felépített állami lakásoknak már több mint 70\%-a házgyári technológiával készültt, ez az építkezés vált egyeduralkodóvá. Óriási, ötéves átfutású lakótelepmonstrumok épuultek ekkoriban 5-15000 lakással, gyakran 35-40 000 
lakost tömörítve (Iván 1996). A felépülö lakótelepek egyre inkább a város szélére szorultak, ahol még nagy, eddig „feltáratlan" területek kínáltak olcsó beépítési lehetöséget.

Az 1970-es években központi kérdéssé vált az átadott lakások száma, így válhatott gyakorlattá a hibás lakások átadása és átvétele, majd későbbi, beköltözés utáni kijavitása. A költségek minimalizálása miatt központi kérdésşé vált a fajlagos költségek kérdése, melyet a szanálási költségek, az új közlekedési és közüzemi beruházások, valamint a megépítendö közintézmények nagyban befolyásoltak. Költségcsökkentés egyedül a közintézmények megépítésének elhagyásával volt lehetséges, amit sajnos egyre általánosabban alkalmaztak, s később ez e lakótelepek egyik legsúlyosabb hiányosságává lépett elỏ.

A hetvenes évek végétől azonban a mennyiségit egyre inkább felváltotta a minőségi szemlélet. Örvendetes tény, hogy az előzỏ évtizedhez képest minimálisra csökkent az egyszobás, s jelentősen megnőtt a két- és háromszobás lakások aránya. A komfortszinvonal is emelkedett, az általánossá váló központi és távfütéssel az összkomfortosság sokáig e lakások legfontosabb minőségi jellemzőjének számított.

$\mathrm{Az}$ időszak a felépülỏ lakótelepek társadalmi összetételében is változásokat hozott. Az 1971. évi lakásrendelet a lakáskiutalást meghatározott jövedelemszinthez, illetve szociális helyzethez - elsősorban a gyermekek számához - kötötte. Így szegényebb rétegek is lakótelepi lakásokhoz juthattak, az új lakótelepek társadalmi státusza ennek megfelelỏen csökkent. Jelenleg az 1970-es évek lakótelepei küzdenek a legtơbb problémával, s bár az ebben az évtizedben megépült lakások az állomány relatív színvonal-emelkedését eredményezték, jelenleg a lakásállomány legkisebb értéket képviseló részévé vảltak. Ezeket a lakótelepeket fenyegeti leginkább a gettóvá válás veszélye (Farkas 1993; Ladányi 1993).

\section{Az 1980-as évek lakótelepei}

Az 1980-as évek lakásépitését mind országos, mind fỏvárosi szinten az állami lakásépítés folyamatos csökkenése és a magánerős építkezések növekedése jellemezte. A lakások mind nagyobb arányban épültek a magánerỏ bevonásával, szövetkezeti lakásként, vagy OTP-támogatással örờlakásként. A nyolcvanas évtizedben egyre jobban próbáltak szakítani az előző évtized lakótelepeinek sematizmusával. A lakások és a lakókörnyezet igényesebb kialakításával minden tekintetben jobb minőségü lakótelepek épültek. Természetesen ezek a lakótelepek kedveltebbek is voltak előző társaiknál, presztízsük egyértelmủen meghaladja a hetvenes években épültekét.

A nyolcvanas évek közepétől a lakásépítések és lakásberuházások jelentősen visszaestek, s a folyamat különösen a kilencvenes években gyorsult fel (Hegedüs 1998). A nyolcvanas évek végével gyakorlatilag a lakótelepi építkezések is 
lezárultak Magyarországon, csak néhány kisebb volumenü beruházás befejezése húzódott még át a kilencvenes évek elejére. Új színfoltot jelentenek viszont az 1990-es évek második felében épülésnek indult nyugati típusú lakóparkok, melyek egy új lakótelepi generáció megjelenését vetítik elöre.

\section{A lakáspolitika változásai 1989 után}

1989 után a magyar lakáspiac alapvető változásokon ment keresztül. A lakáspolitika drámai átalakulásának következtében az állam szerepe minimálisra csökkent, míg a magánszektor jelentősége ugrásszerüen megnőtt. A lakáspiac átalakulásával párhuzamosan a legtöbb állami lakást privatizálták. Összehasonlítva más szocialista államokkal, Magyarországon a lakások privatizációjának hosszú története van. Elméletileg 1969-től lehetséges hazánkban a lakások magánosítása, de - köszönhetően a különféle megszorításoknak - 1982-ig a lakásállománynak csak kis százalékát privatizálták (Kovács 1998b). Az 1983-as enyhítések következtében valamelyest vonzóbbá vált a lakások privatizációja, ez azonban 1990-ig továbbra sem vált meghatározóvá. Az állami lakások aránya a hazai lakáspiacon 1980 és 1990 között 25\%-ról 22\%-ra csökkent, de ez sokkal inkább a magánlakások építésének volt köszönhető. A rendszerváltozást követően a privatizáció jelentösen felgyorsult. Különösen Budapesten volt ez jellemzö, ahol az állami lakások aránya 51\%-ról 15\%-ra csökkent 1990 és 1997 között. Mint a politikai-gazdasági változások része, a helyi önkormányzatok (Budapesten a kerületek) lettek az állami lakások tulajdonosai. Kidolgozhatták saját privatizációs stratégiájukat, meghatározva többek között azt, hogy melyik lakás kerül magánkézbe és melyik marad az önkormányzat tulajdonában. A magyar privatizációs gyakorlat nagyon vonzóvá tette a lakóknak lakásuk megvásárlását, különösen a zöldövezetekben és a belső kerületekben. Itt ugyanis a piaci érték többszöröséért lehetett eladni a lakásokat. Ez a magánosítási rendszer azt eredményezte, hogy a jobb helyzetben lévő családok a legértékesebb és legjobb minőségủ lakásokat vásárolhatták meg, és ezek újraeladásán keresztül nagyobb vagyonra is szert tehettek.

Jelenleg az állami lakások két formában fordulnak elö: a) a belső városrészekben található, a századfordulón épült bérházak lakásai, b) a szocialista időszakban felépült lakótelepi lakások. A privatizáció és a munkaerỏpiac átalakulása jelentősen megváltoztatta a lakásmobilitást is, ugyanis a fiatalabb és jobb anyagi háttérrel rendelkező családok folyamatosan elhagyták az állami lakásokat és a magánszektorba vándoroltak. Így az állami szektor megmaradt a szegény és hátrányos helyzetü társadalmi rétegek menedékéül.

A rendszerváltozás után bekövetkezett átalakulás egyik legfontosabb mozzanata tehát a lakásállomány privatizációja volt. Ebbe a folyamatba természetesen a lakótelepek is bekerültek, s országos szinten a lakótelepi lakásállomány mindössze 
5-6\%-a maradt önkormányzati kézben. Összességében megállapítható, hogy a lakótelepek a privatizáció veszteseinek tekinthetök. Erre utal az a tény is, hogy a kilencvenes évek első felében a lakótelepi lakások ára a névérték emelkedése ellenére mintegy 50\%-os reálérték-veszteséget mutatott. A különbözö generációjú lakótelepek piaci megítélése azonban korántsem volt egyforma. A lakótelepek generációi épített, társadalmi és természeti környezetüket tekintve jelentős különbségeket mutatnak. Mindez a különbözö generációk lakáspiaci megítélésében is lemérhetö, hiszen a városon belüli elhelyezkedéssel, az épített környezettel és a lakótelep image-ével szorosan összefügg a lakótelep piaci helyzete. A nagy lakótelepek, amelyek periferikus vagy környezetileg előnytelen helyen épültek fel és lakásállományuk státusza is alacsonyabb, értelemszerúen kisebb értéket képviselnek a lakáspiacon. Ugyanakkor a kisebb lakótelepek jobb környezetben, közlekedésileg kedvezőbb helyen, jobb lakásaikkal magasabb értéket képviselnek. Legkedvezőbb helyzetben a nyolcvanas évek elitlakótelepei voltak, az itt található lakások ára ugyanis lépést tudott tartani az inflációval. A többi generáció esetében már egyértelmü reálérték-csökkenésröl beszélhetünk. Meglepő az ötvenes évekbeli lakótelepek viszonylag kedvező helyzete, ami többek között e telepek tradicionális építési technológiájára, emberi léptékére, kedvező fekvésére vezethető vissza. A lakáspiaci leértékelödés különösen a hetvenes években felépült lakótelepek esetében volt szembetünő, jelenleg ezek küzdenek a legtöbb problémával ezen a téren. A lakótelepi lakásárakban megmutatkozó különbségek a mobilitást is gátolják, hiszen azoknak, akik beköltöztek ezekre a rossz státuszú lakótelepekre, elég kis esélyük nyílik a továbbköltözésre. A csökkenö piaci árak és az alacsony mobilitás következtében ezek a telepek gyakran kis, különálló szigetekké váltak a város szövetében (Kovács-Douglas 1996).

\section{A Havanna lakótelep}

Az I. világháború elött a XVIII. kerületi (Pestszentlörinc) Havanna lakótelep helyén még gyár állt. A húszas években a gyár helyiségeit szükséglakásokká alakították át a szegényebb rétegek lakáshelyzetének javítására, számtalan munkanélkülinek, hadirokkantnak és menekültnek szoba-konyhás vagy szerényebb lakást biztosítva ezáltal. A fallal körülvett lakótelepen - amely gyakorlatilag külön városrészként funkcionált Állami lakótelep néven - a harmincas évek végén már mintegy 10000 ember élt nagyon egészségtelen körülmények között. A II. világháború után a telepet lebontották, s helyén építették fel a mai Havanna lakótelepet. A házgyári technológiával készült tízemeletes épületek két ütemben készülttek el: 1976 és 1981 között megépült a telep nagyobbik része, majd 1987-1988-ban újabb épületeket húztak fel a területen. 
Jelenleg a 140 önálló házszámmal rendelkező házgyári technológiával előállított tízemeletes panelépületekben 6230 lakás található, ami a kerület lakásállományának 16,6 százaléka. A lakótelepen található lakások többsége 1,5-2-szobás, 55-75 $\mathrm{m}^{2}$ alapterületü. A szocialista időszakban a telepen magán (szövetkezeti), illetve állami (tanácsi) lakások épültek, ezek között már korábban is jelentős minőségbeli különbségek mutatkoztak. A szövetkezeti lakások egyértelmủen jobb állagúak voltak, mint a tanácsiak, s ez a különbség a rendszerváltozás után még tovább nőtt. A rendszerváltozás elött a magántulajdonban lévő lakások aránya $31 \%$ volt, elsősorban szövetkezeti formában, míg a fennmaradó rész állami kézben volt. Ezek az arányok 1989 után drámai módon és gyorsasággal változtak meg. A legtöbb állami lakást nemcsak a Havannán, hanem a város más területein is - a fizikai állapottól függően - a megállapított piaci érték 15-45\%-áért árulták. Ugyanakkor a lakóknak készpénzzel történő fizetés esetén az árnak csak 60\%-át kellett kifizetni, így a tényleges piaci ár 9\%-áért már lakáshoz lehetett jutni. Ez a liberalizált privatizációs gyakorlat tette lehetỏvé a gyors lakáspiaci átalakulást, aminek következtében az állami lakások aránya a Havannán 1999 végére a korábbi 69\%-ról 5\%-ra esett vissza (2. ábra).

\section{2. ÁBRA}

A Havanna lakótelep lakásainak tulajdonviszonyai (Housing Ownership structure in Havanna Housing estate)

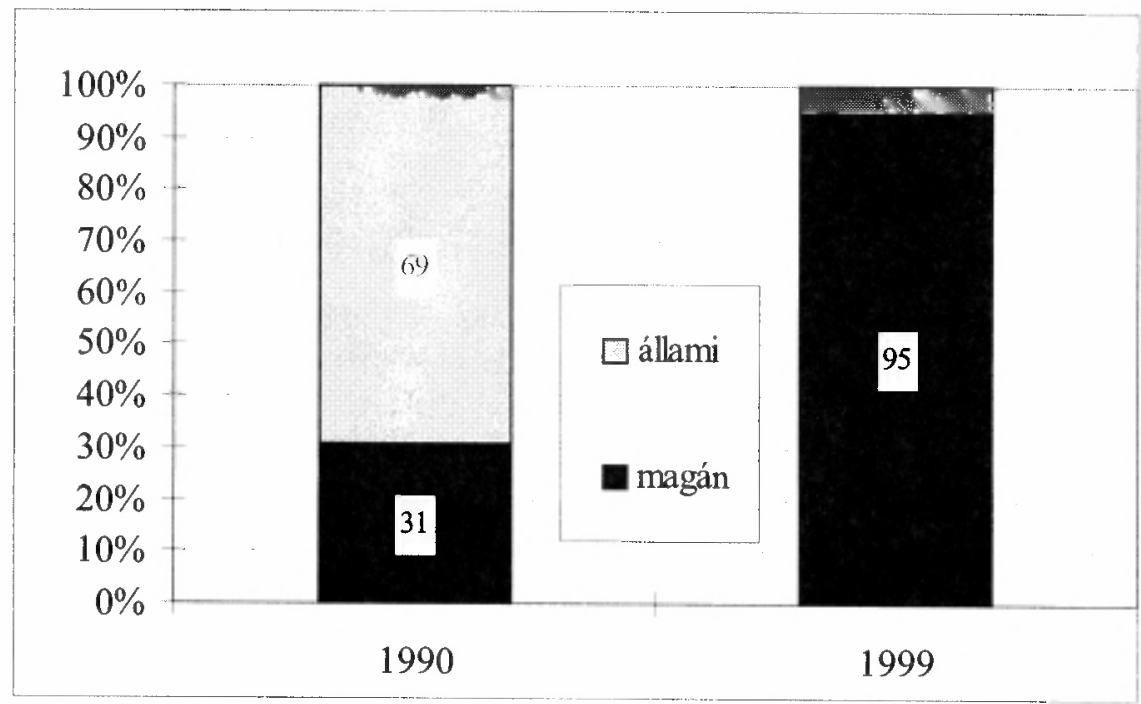

Forrás: KSH.

A Havanna lakótelep népessége megközelítőleg 19400 fö, vagyis a XVIII. kerület lakónépességének 19\%-a él itt. A népesség korösszetétele a lakótelepekre jellemző 
struktúrát mutatja, azaz átlag feletti a gyermekkorúak és átlag alatti az időskorúak aránya. A lakónépesség kor szerinti összetétele - összehasonlítva a budapesti átlaggal - tehát fiatal, a gyerekkorú népesség $(15<)$ aránya megközelítőleg $30 \%$, míg a 60 év felettiek aránya 10\% alatt marad (3. ábra).

\section{3. ÁBRA}

A lakónépesség kor szerinti megoszlása (1990)

(Demographic Profile of Population in comparison)

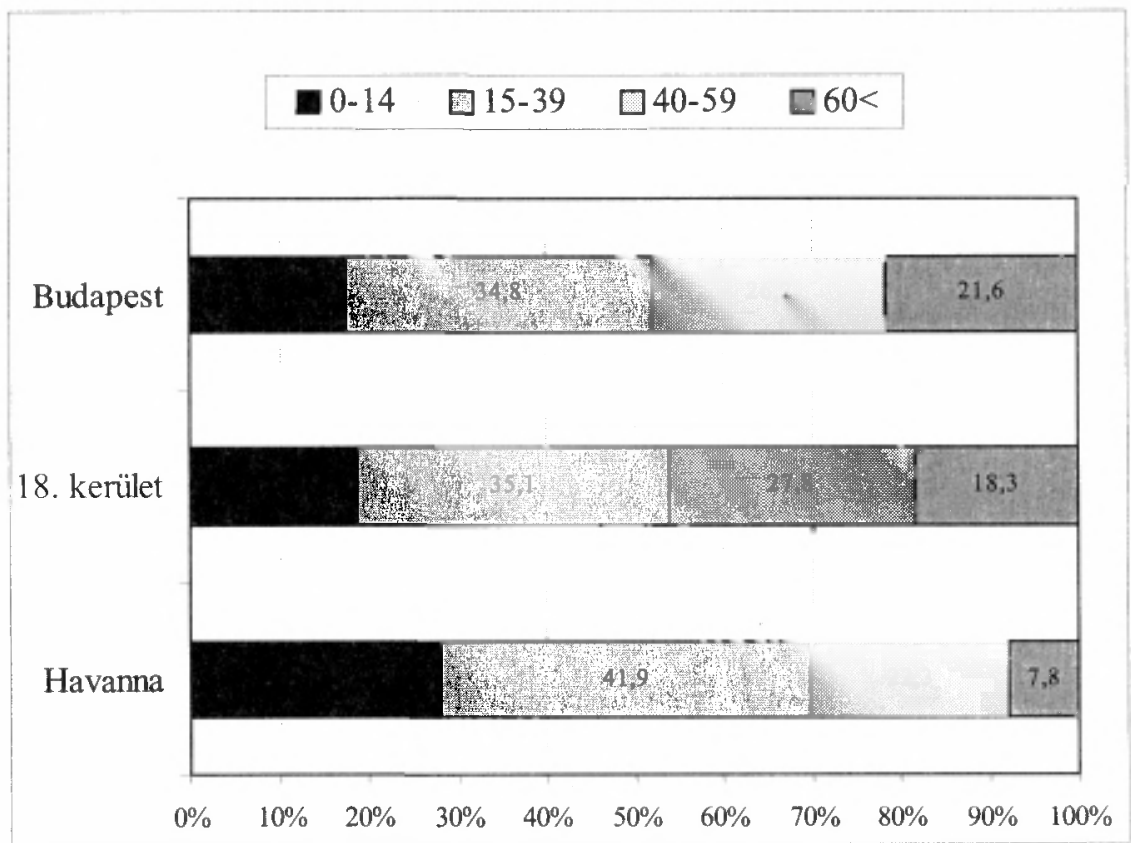

Forrás: KSH.

A lakótelep népességének más demográfiai mutatói is különböznek a fövárosi, illetve kerületi viszonyoktól. A belső kerületekkel ellentétben alacsony az egyedülállók, egyszemélyes háztartások aránya, meglepöen magas viszont a gyermeküket egyedül nevelök (csonka családok) aránya. Az elváltak aránya is lényegesen magasabb, mint a budapesti vagy kerületi átlag, ami talán az 1980-as és 1990-es években tapasztalható társadalmi-szociális krízissel hozható összefüggésbe, mely elsősorban a fiatal, szegény, illetve az átlagosnál alacsonyabb végzettségú rétegeket érintette (4. ábra).

A foglalkoztatottság szempontjából az aktív keresők aránya meghaladja az 50\%-ot, míg fơvárosi szinten ez az érték 42,9\%. A Havanna lakótelep népességének iskolai végzettségét vizsgálva megállapíthatjuk, hogy az jelentösen eltér az átlagtól. A lakótelepi népesség általában magasabb iskolai végzettséggel rendelkezik, mint az átlag, a Havannán az egyetemi és föiskolai végzettségủek 
aránya $(10,7 \%)$ azonban elmarad mind a budapesti $(19,1 \%)$, mind a kerületi $(11,3 \%)$ mutatóktól.

\section{4. ÁBRA}

A Havanna népességének néhány szociális mutatója (1990)

(Social Profile of Havanna Housing estate)

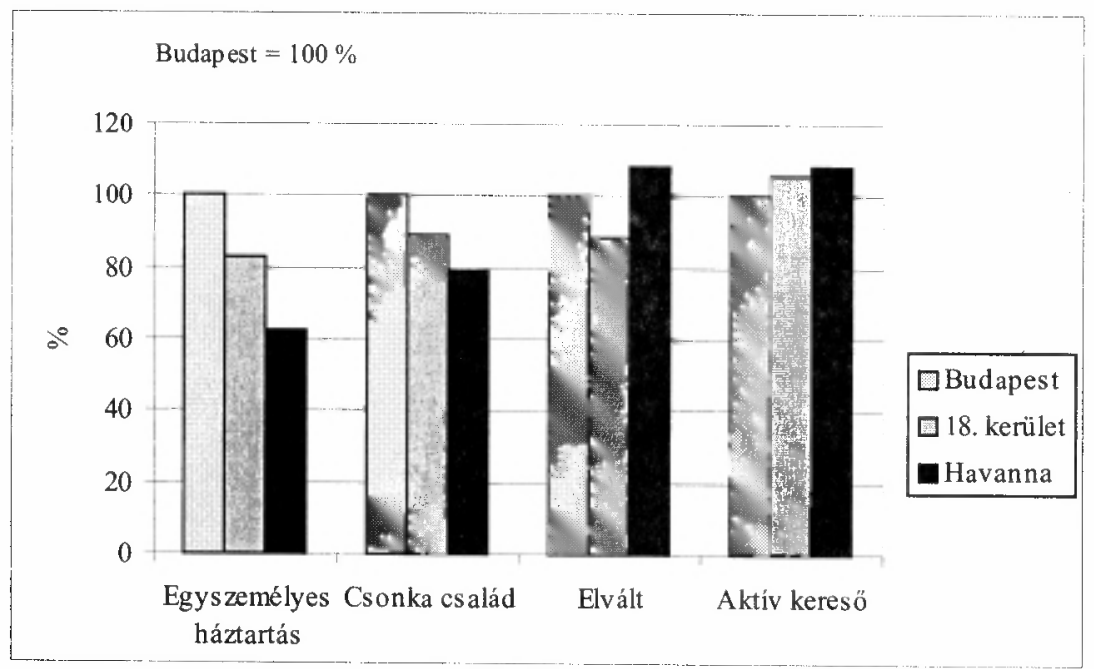

Forrás: KSH.

\section{A cigányok Magyarországon és Budapesten}

Napjainkban a cigányok száma (a roma szervezetek hivatalos becslései alapján) kb. 500000 fö, tehát az ország lakosságának 5\%-a.

A cigányok, vagy romák Északnyugat-Indiából, Punjab területéröl származnak. Első csoportjaik a 15. században a török megszállással kerültek Európába, első hazai említésük is erre a századra tehető. Jelentősebb beáramlásuk az ország területére azonban több hullámban ment végbe. A cigány bevándorlás legnagyobb hulláma a történelmi Magyarország területére a 16. és 17. században történt, s elsősorban az ország déli és keleti régióit érintette. Az elvándorlás kiindulási helye alapján a cigányoknak több csoportja van jelen Magyarországon, melyek mind letelepedési helyüket, mind egyes hagyományaikat és kulturális jellemzöiket, söt néha nyelvüket tekintve is különböznek egymástól. Antropológiai jegyeiket tekintve azonban egyértelmủen megkülönböztethetők a magyar népességtől, ami sokszor alapja az őket érő rasszista megnyilvánulásoknak. A történelem során évszázadokon keresztül vándorló életformát folytattak, aminek kulturális és mentális nyomai még ma is felfedezhetök és gyakran konfliktusforrásként szerepelnek. 
A cigányság egészen az 1970-es évekig vidéki népesség volt, ekkor a kommunista párt elhatározta a romák integrálását és asszimilációját a magyar társadalomba. Többek között e politikának a része volt a vidéki, alacsony színvonalú cigánytelepek felszámolása, és a romák beköltöztetése a lakótelepekre. Ennek következtében a hetvenes és nyolcvanas években jelentősen felgyorsult a városi cigányok arányának növekedése. A rendszerváltozás idején a magyar cigányságnak kb. 40\%-a élt városokban. 1990 után sem szünt meg azonban a cigányok városba áramlása, söt egyes területeken még fokozódott is. A cigány családok a jobb munkalehetőség reményében olyan urbanizált centrumokat vettek célba, mint Budapest, Miskolc, Debrecen. Míg 1971-ben a cigányság 7,9\%-a élt a fỏvárosban, ez az érték 1994-re elérte a 9,1\%-ot. Az 1990-es évek közepén tehát a cigányoknak már mintegy 10\%-a, azaz 50-55 000 fỏ élt Budapesten. Az új lakásrendszer szintén fokozta a cigányok városokba áramlását. A leromlott belvárosi lakónegyedekben és a paneles lakótelepeken az állami szektor még mindig fontos szerepet játszik azáltal, hogy alacsonyabb színvonalú, de olcsó szociális bérlakásokat biztosít szegényebb családok számára. A legtöbb fiatal vagy jobb helyzetben lévő család elköltözött ezekböl a városrészekböl, ezáltal megindulhatott a szegényebbek (különösen a cigányok) beköltözése ezekre a területekre. A cigány népesség elhelyezkedése a fővárosban jellegzetes képet mutat: a legtöbb roma a pesti oldalon, a VII. (Erzsébetváros), VIII. (Józsefváros) és a XX. (Pesterzsébet) kerületekben koncentrálódik. A XVIII. kerület (Pestszentlörinc), ahol mintaterületünk, a Havanna lakótelep található, a cigányság számát tekintve átlagosnak mondható. A romák száma itt 5-6000 före tehetö, ami megközelítöleg a kerület lakosságának 5\%-a. A cigányok aránya a Havanna lakótelepen ugyancsak 5\%, amiböl arra következtethetünk, hogy a lakótelep még nem indult meg a gettósodás útján. Felmerül azonban a kérdés, hogy milyen folyamatok megindulása várható a jövőben?

\section{A kutatás módszere}

A társadalmi kirekesztés mint szociális rétegjelenség vizsgálható. Napjainkban a "two-speed-society" és a "dual city" elmélete a szegénység vizsgálatáról a figyelmet a társadalmi kirekesztés (szegregáció) jelenségének feltárására irányította. A társadalmi kirekesztés kérdése egy sor abszolút és relatív összetevőt tartalmaz, melyek különböző társadalmi és kulturális helyzetben jelentősen eltérhetnek egymástól. Így nem elég kizárólag a szegény rétegek anyagi helyzetét, ellehetetlenülését vizsgálni, hanem arra is figyelmet kell fordítani, hogy ezek a rétegek képtelenek társadalmi, kulturális és politikai jogaik (pl. munka, egészséges élet, oktatás, minimálbér stb.) gyakorlására. Az ezen a téren tapasztalható hátrányos helyzet (szegénység, tartós munkanélküliség, rossz egészség, alacsony életszínvonal, alacsony mobilitás stb.) és ezek kombinációi akut kirekesztettséghez 
vezethetnek, ami a társadalom legszélére történő kiszorulást eredményez. Ez a folyamat gyakran térben is megjelenik és manifesztálódik a városszéli hátrányos lakótelepeken, s megtalálható mind individuális, mind pedig szomszédsági szinten.

Kutatásunk elsődlegesen kvalitatív mélyinterjúkon alapul. Az interjúk alanyai véletlenszerủen kiválasztott helyi lakosok (háztartásfők) voltak. A velük készitett interjúk mindennapi életükröl alkotott szubjektív véleményüket is feltárta, ami könnyebbé teszi annak megitélését is, hogyan befolyásolja a munkaeröpiac és a lakáspolitika életüket, $\mathrm{s}$ találhatunk-e összefüggéseket ezek és a társadalmi kirekesztés között. Bár ez a felmérési technika kevésbé teszi lehetôvé reprezentatív minta kiválasztását, fontos volt olyanokat is megkérdezni, akiket ez a fajta kirekesztés valóban veszélyeztet. Ennek megfelelően két mintát választottunk: magyar háztartások (20 interjú) és cigány háztartások (14 interjú). Mindkét esetben a családfökkel (háztartásfökkel) beszélgettünk. Tanulmányunkban az interjúk eredményeiböl azon jellemző különbségek kerülnek bemutatásra, amelyek a magyar és a roma lakosság között szignifikánsan - azaz gyakorlatilag teljesen eltérnek.

A kvalitatív mélyinterjús felmérés a következö kérdésekre kereste a választ:

1) Milyen változások álltak be a rendszerváltozás óta a lakótelepi lakosok foglalkoztatottsági és lakáshelyzetében?

2) Hogyan értékelik az interjúalanyok tágabb lakókörnyezetüket (a Havanna lakótelepet)?

3) Milyen különbségek fedezhetök fel a cigány és magyar családok helyzetében, tekintettel a munkaerópiacra és lakáshelyzetre? Ezek milyen hatást gyakorolnak a társadalmi kirekesztés szintjére?

Az interjúk a következő adatok feltárására összpontosítottak:

1) Személyi adatok (kor, nem, iskolai végzettség, háztartás összetétele stb.)

2) Foglalkoztatottsági helyzet (munkaerö-piaci karrier, helyzet a rendszerváltozás elött és után, munkanélküliség veszélyei stb.)

3) A család anyagi helyzete (bevétel, források, alapvető szükségleti cikkek stb.)

4) A lakás helyzete (minösége, tulajdonviszonyai, beköltözés ideje, az elöző lakásból történö elköltözés okai, befektetések a lakásba, elégedettség, elköltözési szándék stb.)

5) A lakókörnyezet (az ittélés elónyei, hátrányai, társadalmi kapcsolatok, közbiztonság, helyi szolgáltatások, közösségi aktivitás, a lakótelep image-e, remények és törekvések, magyar-cigány kapcsolatok, etnikai problémák) 


\section{A felmérés legfontosabb eredményei, megállapitásai}

\section{A családok és háztartások}

A XVIII. kerület cigány lakosságának megközelítőleg háromnegyede származik a fövárosból. 34\%-a tösgyökeres a kerületben, azaz már szülei is itt laktak, 55\% négy évnél régebben költözött ide, többségében Budapeströl (55\%), emellett faluról és vidéki városokból is érkeztek. Mindössze 11,5\% költözött a kerületbe az elmúlt négy évben. Jellemzö, hogy a cigány családok általában a fövároson belül mozognak.

A XVIII. kerületben minden harmadik cigány családban egy szülő neveli a gyermeket (általában egyet). Jellemzỏ a háztartások összetételére, hogy minden harmadik háztartásban több család él együtt, $\mathrm{s}$ ezek a többcsaládos háztartások elsősorban a lakótelepek panelházaira koncentrálódnak. Nem véletlen tehát, ha az önkormányzati adatokat saját felméréseink is alátámasztják: a Havanna lakótelepen amellett, hogy a cigány családok alapvetően nagyobbak, mint a magyarok, meglepően magas az egyszülős családok aránya. A Havannán tipikusnak mondható, hogy a már felnőtt (gyakran munkanélküli) gyerekek a szülökkel és fiatalabb testvéreikkel együtt maradnak, egy háztartásban élnek.

A kerïlet cigányainak egészségi állapota általában sokkal rosszabb a magyarokénál, ami részben az alacsonyabb életszínvonal, részben az életmód következménye. A csecsemőhalálozás több mint kétszerese, a cigány gyerekek életben maradási esélye alig 30\%-a az országos átlagnak. A fiatalok és fiatal felnőttek (15-29 év) halálozási arányszáma nyolcszorosan haladja meg az országos átlagot (5. ábra)!

A cigányok iskolai végzettsége alacsonyabb magyar társaikénál. A Havanna lakótelepen legtöbbször a nyolc általános, de nem ritkán ennél kevesebb szerepel legmagasabb iskolai végzettségként, míg ugyanez a magyaroknál a szakmunkásképző iskola. Ugyanakkor nemcsak a kerületben, hanem a Havanna lakótelepen is a férfiak magasabb iskolai végzettséggel bírnak, mint a nők. Meg kell említenünk azt a tényt is, hogy a cigányok tisztában vannak a tanulás és a magasabb iskolai végzettség fontosságával, $\mathrm{s}$ ha lehetőségük lenne rá, magasabb szinten is taníttatnák gyermekeiket.

\section{Foglalkoztatottsági és anyagi helyzet}

A felmérés során kiderült, hogy a cigányok munkaerö-piaci helyzete nagyot változott az 1990-es évek elejétól. A szocialista időszak alatt gyakorlatilag minden cigány fẻrfi dolgozott, míg a rendszerváltozás után legtöbbjük a munkaerópiac szélére sodródott, és időről időre elvesztette munkáját. Ezen eredmények 
összecsengnek azokkal a szociológiai vizsgálatokkal, amelyek szerint a gazdasági átalakulás legfóbb vesztesei - legalábbis szociális értelemben - a cigányok voltak. Alacsony kvalifikáltságukból kifolyólag ők a lakáspiac legsérülékenyebb csoportja.

\section{5. ÁBRA}

A halálozás korcsoportok szerint (1998)

(Mortality of Age Groups)

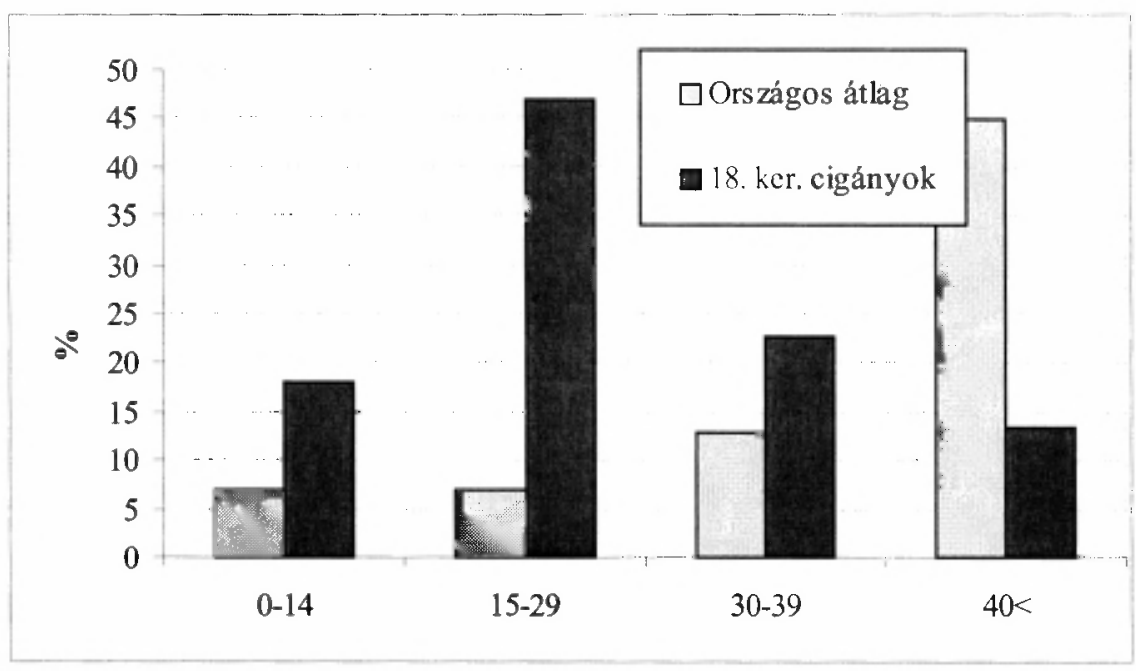

Forrás: XVIII. Kerület Önkormányzata.

Alacsony iskolai végzettségük miatt ugyanakkor a munkanélküliség is sokkal gyakoribb a romák, mint a magyarok között. A legtöbb cigánynak csak átmeneti munkája van, a rendszeresen foglalkoztatottak aránya alacsony, s gazdasági nehézségek esetén a cégeknél őket bocsátják el legelőször. Jellemző tehát a bizonytalanság, és a munkaerôpiac peremén való mozgás. Az önkormányzat kerületi szinten végzett felmérése rámutat a cigány férfiak és nők közötti alapvetö különbségekre foglalkoztatottság tekintetében: a cigány nöknek mindössze 18,2\%-a dolgozik rendszeresen, míg ez az érték a férfiaknál 41,6\%. A kerület cigányságának harmada a rendszerváltozás óta nem tudott elmozdulni alacsony foglalkoztatási szintjéről, s közel $40 \%$ lefelé mozdult el korábbi szintjéhez képest: szakmunkásból betanított, majd segédmunkás lett (6. ábra).

A munkanélküliség a Havannán nem kizárólag a roma lakosság sajátja, hiszen az alacsony képzettségủ magyarokat is sújtja. Az elmúlt 10 évben mind a magyar, mind a cigány családok felét legalább egyszer érintette valamilyen formában a munkanélküliség. Az alapvetö különbség azonban a két csoport között a lakótelepen, hogy míg a magyarok próbálnak tenni valamit (továbbképzés, 
tanfolyamok stb.) munkaerö-piaci helyzetük javítására, erősítésére, a cigányok elég passzívnak mutatkoznak ezen a téren.

A foglalkoztatottsági helyzet alapvetően befolyásolja a családok anyagi lehetöségeit is. A magyar családok helyzete ezen a téren lényegesen jobb a Havanna lakótelepen. Ez alapvetően a következő okokra vezethető vissza:

a) a magyarok általában rendszeres és magasabb jövedelemmel rendelkeznek, mint a romák,

b) a cigány családok általában nagyobbak, mint a magyar családok (3-4 gyerek),

c) míg a cigányok gyakran szociális juttatásokból és segélyeken, a magyarok rendszeres fizetésböl élnek. Emellett gyakori a cigány családoknál, hogy alkalmi pénzzavaraik fedezésére rokonoktól, ismerősöktől kérnek kölcsön.

\section{6. ÁBRA}

A XVIII. kerület cigányságának foglalkoztatottsági helyzete (1998)

(Employment of Roma in $18^{\text {th }}$ District)

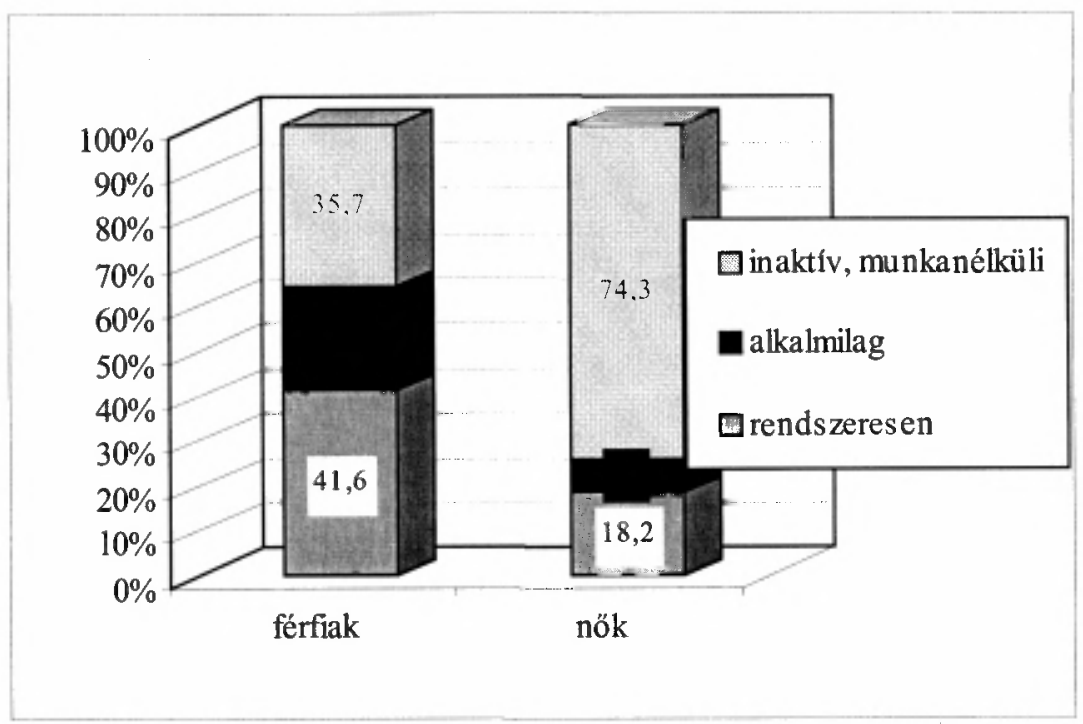

Forrás: XVIII. Kerület Önkormányzata.

$\mathrm{Az}$ anyagi körülményekre kerületi szinten jellemzö, hogy a cigány családok háromnegyede igen rossz, vagy szegényes körülmények között él. A XVIII. kerületi romák $10 \%$-a nyomorog, $54 \%$-a rossz körülmények között él, de nem nyomorog, $31 \%$-ának jó a helyzete, de nem jut mindenre, s mindössze a megkérdezettek 5\%-a ítélte helyzetét minden tekintetben jónak. A Havanna lakótelepre jellemzö, hogy a cigány háztartásokban is mindennaposnak mondható a színes TV és a video, ezen felül azonban a magyar családok többsége automata mosógéppel, mobiltelefonnal és autóval is rendelkezik, ami a cigány családokról már nem állítható. Fontos 
kihangsúlyozni azt a tényt, hogy mindkét csoport családfői kivétel nélkül úgy nyilatkoztak: helyzetük romlott a rendszerváltozás óta!

Érdekes összefüggésre lettünk figyelmesek eredményeink értékelésekor: megállapítottuk, hogy minél jobb anyagi helyzetben vannak a cigányok, annál nagyobb arányban vallják magukat magyarnak, és annál jobban törekednek a romáktól való elhatárolódásra. A módosabb családok számára egyértelmủen nagyobb a beilleszkedés és gyülöletellenesség utáni vágy. A cigányok között is megfigyelhetö tehát, hogy a cigányságot és a szegénységet bizonyos szinten azonosítják egymással. A fenti tény rámutat arra, hogy a cigányság anyagi helyzetének javításával (nem elsősorban magasabb segélyekkel, hanem munkalehetőségek, esélyegyenlőség, pozitív diszkrimináció megteremtésével) hosszú távon lehetséges lenne e leszakadó rétegek visszaintegrálása a társadalomba.

\section{A lakáshelyzet}

A lakótelepi felmérés válaszadóinak döntő többsége jelenlegi lakóhelyére az 1980-as évek végén érkezett, tehát nem tartoznak a Havanna lakótelep első generációjába. Legtöbbjük kisebb lakásból költözött ide, igaz a város különböző területeiröl. A legtöbb cigány család a XVIII. kerületböl, vagy a belvárosi kerületekböl (cigány gettóöv) érkezett, és általában alacsonyabb színvonalú és komfortfokozatú lakásokat hagytak maguk mögött. A magyarok viszont Budapest egész területéröl érkeztek, s elözö lakásaik is magasabb színvonalúak, általában összkomfortosak voltak. A Havanna lakótelepre történő beköltözés tehát a roma családok esetében inkább egy minőségi, mig a magyarok esetében inkább mennyiségi (nagyobb lakás) változást eredményezett. Általában minden válaszadó a korábbinál jobbnak ítélte jelenlegi lakásköruilményeit. A két mintacsoport között alapvető különbségek fedezhetők fel: a) a lakás tulajdonviszonyaiban, b) a lakásfenntartás költségeiben, c) a lakást érintő beruházások és felújítások tekintetében, d) a lakás piaci értékének megítélésében.

A cigányok szinte kivétel nélkül szociális bérlakásban élnek, míg a magyarok saját tulajdonú lakásokban laknak. A magyar családok 1990 után a privatizáció keretében megvették lakásukat, míg erre az állandó pénzhiánnyal küszködő romák csak nagyon ritkán voltak képesek. A lakások fenntartási költségei a cigány háztartások bevételének sokkal magasabb arányát veszik el, mint a magyarok esetében. A cigány háztartások átlagosan bevételük 50-60\%-át költik lakhatási költségeik fedezésére, míg ez az érték a magyar családok esetében 25-30\%. $\mathrm{Az}$ anyagi lehetőségekben megmutatkozó különbségek nagyon jól mérhetők az elmúlt években vállalt lakásfelújítási munkálatokban is. A legtöbb magyar család elsősorban saját megtakarításból - végzett valamilyen felújítást (tapétázás, festés stb.), és hasonlót a jövöben is tervez, a cigány családoknál mindez ritkaságszámba megy. 
A fentiek hủen tükrözik a kerületi viszonyokat. Kerületi szinten jellemző a cigány lakások túlzsúfoltsága: a budapesti átlagnak kétszerese az egy lakásban és háromszorosa az egy szobában élök száma. A kerület cigányságának 34\%-a rossz és rendezetlen körülmények között él, 38\%-a rendezett, de szegényes lakásokban lakik.

A Havannán élö magyar és roma családok eltéröen ítélik meg ingatlanuk piaci értékét. A hasonló alapterületü és elhelyezkedésü lakásokat a magyarok 10-20\%-kal nagyobb értékűnek becsülték, mint a cigányok. Ennek oka lehet egyrészt a cigány kézben lévő lakások rosszabb állapota, másrészt az is, hogy a romák kevésbé ismerik ki magukat és kevesebb tapasztalattal rendelkeznek a lakáspiacon.

\section{A lakókörnyezet és a társadalmi kirekesztés}

A Havanna lakótelep nemcsak Budapest, hanem az ország egyik legrosszabb image-ủ lakótelepe, ami azonban az itt lakók véleménye szerint nem tükrözi a valós helyzetet. Tény, hogy a Havannán már a rendszerváltozás elött is nagy különbségek voltak tapasztalhatók a szövetkezeti és a tanácsi lakások minőségében, színvonalában. Bár a két lakástípus keveredett a lakótelepen, a szövetkezeti lakások helyzete egyértelmüen jobb volt. A szövetkezeti lakások tulajdonosai jobb anyagi körülményeknek köszönhetően a rendszerváltás után sokkal mobilisabbak voltak, mint a tanácsi bérlakásban élók. Következésképpen sokkal nagyobb arányban költöztek el a lakótelepröl magasabb státuszú lakónegyedekbe. A szociális lakások privatizációja tovább növelte a különbségeket az elmúlt 10 évben. A fiatalabb, illetve jobb anyagi helyzetben lévő családok még a magánosítás első szakaszában megvették lakásaikat és - nem ritkán - hamarosan elhagyták a Havannát. Az 1990-es évek elejétől a Havanna fokozatosan a lakáspiaci láncolat végére csúszott, azaz nagyon könnyủ volt itt lakáshoz jutni, de rendkívül nehéz volt túladni rajta. Azok számára - függetlenül etnikai hovatartozástól, kortól -, akik lakáspiaci helyzetuikön képtelenek voltak valamilyen formában javítani, a Havanna lakáskarrierjük végállomásává vált.

A jövőbeli terveket és a lakáshelyzetet tekintve a romák sokkal pesszimistábban nyilatkoztak. Lakókörnyezetük, a közbiztonság és a helyi szolgáltatások színvonaláról alkotott véleményük sokkal negatívabb volt, mint a magyaroké. Általános véleményük szerint olyan csapdába kerültek, ahonnan külső segítség nélkül reménytelennek mutatkozik a kitörés. A lakás fenntartási költségeinek csökkentéséhez a romák szerint elengedhetetlen a nagyobb szociális támogatás, ami azonban - ismerve a mai magyar helyzetet - eléggé valószínütlennek tünik. Ez ismételten azt támasztja alá, hogy a cigányok a végbemenő folyamatoknak inkább passzív szemlélői, így az sem véletlen, hogy gyakran nosztalgiával viseltetnek a szocialista időszak évei iránt. 
Végül meg kell említenünk egy fontos tényt a magyarok cigányokkal kapcsolatos attitüdjével és érzelmeivel kapcsolatban. A roma válaszadók kivétel nélkül úgy nyilatkoztak, hogy a magyarok a Havannán semmiféle negatív diszkriminációval nem sújtják öket. A társadalmi kirekesztés tehát sokkal inkább kapcsolható a kapitalista változásokhoz, a munka- és lakáspiachoz, mintsem a társadalom szociokulturális diszkriminációjához! Vagyis a cigányság makroszintủ kirekesztése nem, vagy kevésbé párosul mikroszintũ lakóhelyi diszkriminációval.

\section{Összefoglalás}

A II. világháború után felépült lakótelepek épített környezetében, amely alapvetően hatást gyakorol e lakónegyedek társadalmi és természeti környezetére is, alapvetö különbségek fedezhetök fel az egyes generációk között. Ennek köszönhetően a rendszerváltozás után az egyes lakótelepi generációk lakásai eltéró eséllyel indultak a lakáspiacon és léptek be a privatizációs folyamatba. A lakásárak szabályozó hatására a lakótelepek különbözö generációinak népességében megindult egyfajta „letisztulási” folyamat, amelynek követeztében ezen generációknál - több kísérőjelenséggel együtt - egyre inkább felismerhetö az egységes lakásosztályokká történö átalakulás folyamata. Ebben a tekintetben legnagyobb problémákkal az 1970-es években felépült városszéli, nagypanelos lakótelepek küzdenek, amelyek potenciálisan leginkább magukban hordozzák a gettósodás veszélyét.

Napjainkban egyre jobban felismerik, hogy a poszt-szocialista városokban nagy figyelmet kell fordítani a hátrányos helyzetben lévő családokra. Valószínủleg a hátrányos helyzet és a szociális erózió legjobb példái (beleértve a belvárosi gettókat is) a nagy lakótelepek. Ez a tanulmány a Havanna lakótelepen 1998/99-ben a társadalmi kirekesztés témakörében végzett kutatási eredményeket foglalja össze. Mint kutatásaink mutatták, a még nem gettósodó lakótelepek magyar és cigány lakosságának helyzetében alapvetỏ különbségek fedezhetők fel, melyek könnyen vezethetnek a szegregációs és gettóképződési folyamatok felgyorsulásához. E különbségek kimutathatók többek között a cigány háztartások eltéró összetételében (többcsaládos háztartások, csonka családok magasabb aránya), a rosszabb egészségi állapotban (magasabb halálozási arányszámok fiatalabb korban) és az alacsonyabb iskolai végzettségben is. Szociális krízisüket erősíti rosszabb foglalkoztatottsági és anyagi helyzetük (gyakori alkalmi munka, rendszertelenebb és alacsonyabb fizetés, segélyek nagyobb szerepe), valamint hátrányos lakáshelyzetük is (rossz állapotú szociális bérlakás). Nem véletlen tehát, ha jövőbe vetett hitük, elképzeléseik és stratégiáik egyértelmüen pesszimizmust sugároznak.

Bebizonyosodott, hogy a társadalmi kirekesztés a munkaerö- és lakáspiac kapitalista átalakulásának az eredménye. Az alacsony képzettségủ, alacsonyabb és rendszertelen keresettel rendelkező emberek egyre inkább a társadalom szélére 
szorulnak. Ez azonban a magyarokra és a romákra egyaránt vonatkozik. Tapasztalataink azt mutatják, hogy a cigányok munkahelyi, munkaerö-piaci diszkriminációja nem - vagy legalábbis elhanyagolható mértékben - párosul helyi szintü, környezeti diszkriminációval. Az is kiderült, hogy az életstratégiát és a jövöbeli célokat illetően sokkal optimistább egy szegény magyar, mint egy cigány, aki inkább passzív szemlélöje az elmúlt évek változásainak. Sürgẹtő, sőt azonnali feladat lenne, hogy ezeket a lecsúszott és lecsúszóban lévő rétegeket valamilyen formában visszaintegráljuk a munkaerőpiacra, megelőzve ezzel a társadalmi kirekesztés növekedését és a megelőzhető feszültségek kialakulását a társadalmon belül. Ez döntő lehet a lakótelepek jövőjére nézve is, különösen az olyan problémás telepeken, mint a Havanna. Egy ilyen integrációs program megvalósításával a rossz image-ü, alacsony státuszú lakótelepek talán visszakerülhetnének a lakáspiac fö áramlatába. Amennyiben ez nem valósul meg, a nagy városszéli lakótelepek a jövőben lényegesen nagyobb problémát fognak jelenteni, mint amekkorát jelenleg magukban hordoznak.

\section{Irodalom}

A cigány családok helyzete és perspektívai a XVIII. kerületben. (1998) Helyi Társadalom Fejlesztéséért Alapítvány szociológiai kutatása.

Csanádi G.- Ladányi J. (1992) Budapest térbeni-társadalmi szerkezetének változásai. Akadémiai Kiadó, Budapest.

Dunleavy, P. (1981) The Politics of Mass Housing in Britain 1945-1975. Clarendon Press, Oxford.

Farkas E. J. (1993) Az önkormányzati tulajdonú bérlakások eladása. - Statisztikai Szemle. 8-9. 739-740.o.

Hegedüs, J. (1987) Reconsidering the roles of the state and the market in socialist housing systems. International Journal of Urban and Regional Research 11. 1. 79-97. 0.

Hegedüs J. (1998) A magyar lakásszektor piaci átalakulásának ellentmondásos folyamata. - InfoTársadalomtudomány. 43. 49-58.o.

Herlyn, U. (1989) Upgrading and downgrading of urban areas. - Tijdschrift voor Economische en Sociale Geografie. 80. 97-105.0.

Iván L. (1996) Mégegyszer a budapesti lakótelepekröl. Tér-Gazdaság-Társadalom. Huszonkét tanulmány Berényi Istvánnak. - Dövényi Z. (szerk.), MTA Földrajztudományi Kutatóintézet, Budapest. 49-80.o.

Kempen, E. Van-Musterd, S. (1991) High-rise Housing Reconsidered: Some Research and Policy Implikations. - Housing Studies. 6. 2. 83-95.0.

Kovács Z.-Douglas, M. (1996) A városépítés idozített bombája - avagy a magyar lakótelepszindróma társadalomföldrajzi megközelítésben. - Földrajzi Értesítö. 1-2. 101-117.o.

Kovács, Z. (1998a) Ghettoization or gentrification? Post-socialist scenarios for Budapest. - Neth. J. of Housing and the Built Environment. 13. 1.63-81.o.

Kovács, Z. (1998b) Social and Economic Consequences of Changing Housing Policies in Hungary. Social Housing: International Comparison of Planning for the Weakest Social Groups. - Holt-Jensen, A.-Morrison, N. (eds.), Geography in Bergen, Series B. 98-107.o.

Ladányi, J. (1993) Patterns of residential segregation and the Gypsy minority in Budapest. - Internal Journal of Urban and reegional Research. 17. 4. 30-41.0.

Muiller, E. (Hrsg.) (1997) Großsiedlungen in europäischen Städten. Institut für Länderkunde. Leipzig.

Preisich G. (1998) Budapest városépítésének története 1945-1990. Müszaki Könyvkiadó, Budapest. 
Ravetz, A. (1985) Problem housing estates in Britain: The case of Quarry Hill Flats and Hunslet Grange, Leeds. Post-war Public Housing in Trouble. - Park-Premius (eds.), University Press, Delft.

Rietdorf, W.-Liebmann, H-Knorr-Siedow, T. (1994) Großsiedlungen in Mittel- und Osteuropa. - Regio. Beitrăge des IRS, 4.

Szelényi I. (1990) Városi társadalmi egyenlötlenségek. Akadémiai Kiadó, Budapest.

Szelényi I.-Konrád Gy. (1969) Az új lakótelepek szociológiai problémái. Akadémiai Kiadó, Budapest.

Tuppen, J. (1995) After Les Minguettes: 'Problem' Housing Estates in France. - European Urban and Regional Studies. 2. 4. 367-371. o.

\section{SOCIAL EXCLUSION AND THE HOUSING ESTATES}

\section{TAMÁS EGEDY}

Housing estates are peculiar segments of the housing market due to their scale, location, homogenity and last but not least their social structure. Housing estates cannot be considered merely as products of the former state-socialist system since they can also be found in Western Europe, but the problems related to housing estates turn up in the East-Central European countries more severe, since the number of dwellings located on housing estates and consequently their weight on the housing market go far beyond the West-European scales.

According to our hypothesis the remnants of public housing stock especially the less popular and marketable forms like high rise housing estates are now becoming the shelter of urban poor increasingly in post-socialist cities. Thus, housing policy (or the lack of it) and the functioning of housing market contribute actively to the marginalisation and exclusion of certain social groups. In this paper we highlight some of the characteristics of social exclusion in Budapest using the example of high-rise housing estates. First the genesis of housing estates and the transformation of housing policy after 1989 are discussed. Then the empirical part of the paper draws findings from household interviews carried out at one of the typical problematic housing estates of Budapest, the Havanna housing estate. During our research special emphasis has been paid to the mechanism of exclusion, deprivation, lack of resources, acces to public services. Special attention is paid to factors of social exclusion such as ethnicity, poverty, labour market situation etc. 